\title{
Effects of Soy Foods in Postmenopausal Women: A Focus on Osteosarcopenia and Obesity
}

\author{
Sijia Tang, Yang Du, Chorong Oh, Jaekyung No* \\ Department of Food and Nutrition, Kyungsung University, Busan, Korea
}

Chronic diseases in postmenopausal women are caused by rapid changes in hormones and are accompanied by rapid changes in body composition (muscle, bone, and fat). In an aging society, the health of postmenopausal women is a social issue, and people's interest in ingesting high-quality protein is increasing in order to maintain a healthy body composition. This review aims to summarize the efficacy of soy foods and their impact on body composition. The soy protein and isoflavones contained in soy foods can improve muscle and bone density quality and reduce body weight. It is considered a breakthrough in preventing osteosarcopenia and obesity that may occur after menopause.

Key words: Postmenopause, Body composition, Osteosarcopenia, Obesity, Soy foods, Isoflavones

\author{
Received January 8, 2020 \\ Reviewed January 22, 2020 \\ Accepted May 1, 2020 \\ *Corresponding author \\ Jaekyung No \\ (iD) \\ https://orcid.org/0000-0003-2433-346X \\ Department of Food and Nutrition, \\ Kyungsung University, 309 Suyeong-ro, \\ Nam-gu, Busan 48434, Korea \\ Tel: +82-51-663-4651 \\ Fax: +82-51-663-4651 \\ E-mail:jkno3@ks.ac.kr
}

\section{INTRODUCTION}

The body composition (BC) of postmenopausal women changes rapidly due to hormonal changes, including the loss of bone (osteoporosis) and muscle (sarcopenia), usually in the presence of increased adiposity and fat redistribution towards central-type obesity. ${ }^{1-3}$ Osteosarcopenic obesity is a newly described syndrome describing coexistence of osteoporosis and sarcopenia with fat increase during aging (Table 1$){ }^{4}$

Soy foods are currently the subject of extensive research, mainly because they are a unique and abundant source of isoflavones. Due to the limited public data on the soy-bone relationship, soy foods often exhibit a positive effect on bone health. A 3-year longitudinal study of 116 premenopausal Chinese young women 30-40 years of age showed that the consumption of soy foods has a potential effect on bone mass. ${ }^{5}$ Soy can also improve the metabolic health of postmenopausal women. ${ }^{6}$ In laboratory animals, dietary soy protein intake is associated with obesity, decreased blood glucose and insulin, and improved lipid distribution and insulin sensitivity, so this shows that soy foods are effective in improving obesity. ${ }^{7-9}$ Although research on soy foods remains controversial, ${ }^{10}$ as a source of highquality protein, it is important for maintaining $\mathrm{BC}$ in postmenopausal women.

\section{DISEASES CAUSED BY CHANGES IN BODY COMPOSITION}

\section{The dangers of osteosarcopenia in postmenopausal} women

Sarcopenia (loss of muscle mass and strength) and osteoporosis (bone loss) are the two most common chronic diseases in the elderly. Given the clear interaction between bone and muscle, this

Copyright (C) 2020 Korean Society for the Study of Obesity

(a) This is an Open Access article distributed under the terms of the Creative Commons Attribution Non-Commercial License (https://creativecommons.org/licenses/by-nc/4.o/) which permits unrestricted non-commercial use, distribution, and reproduction in any medium, provided the original work is properly cited 
Table 1. Disease syndromes in postmenopausal women ${ }^{4}$

\begin{tabular}{|c|c|}
\hline Disease & Risk factor \\
\hline Osteoporosis/osteopenia & Maternal history of hip fracture \\
\hline Sarcopenia & Low albumin, stroke, hyperlipidemia \\
\hline Osteosarcopenia (osteoporosis/osteopenia and sarcopenia) & $\begin{array}{l}\text { Older age, female, high alcohol intake, oral glucocorticoids, menopause (females), low protein intake, low } \\
\text { body mass index, current smoking status, low dietary calcium, low serum vitamin D, hyperparathyroidism, } \\
\text { obesity, rheumatoid arthritis, living in residential aged-care facilities, chronic kidney disease, low mobility } \\
\text { and function }\end{array}$ \\
\hline Obesity & $\begin{array}{l}\text { Ethnicity, reduced physical activity, reduced lean mass, reduced resting metabolic rate, genetics treatment } \\
\text { with certain drugs e.g., steroids, insulin, glitazones }\end{array}$ \\
\hline $\begin{array}{l}\text { Osteosarcopenic obesity (osteoporosis/osteopenia and sarcopenia } \\
\text { and obesity) }\end{array}$ & Aging, osteoporosis/osteopenia, sarcopenia, fat infiltration, fat redistribution \\
\hline
\end{tabular}

aging syndrome is defined as "osteosarcopenia" when osteoporosis and sarcopenia occur simultaneously. ${ }^{4}$ Currently, the incidence of negative consequences such as falls, fractures, loss of function, weakness, and mortality will increase. ${ }^{11}$ Research by Hamad et al. ${ }^{12}$ confirmed that the prevalence of osteosarcopenia in postmenopausal women is high. Some studies ${ }^{13,14}$ of preselected populations of female patients with hip fractures and falls have found that osteoporosis is more prevalent in patients with osteosarcopenia compared to those with non-osteosarcopenia. Comparing postmenopausal women with only sarcopenia or osteoporosis to postmenopausal women with osteosarcopenia, the latter suffers from poorer body function and a higher risk of fractures, reduced function, and death. Complications of osteopenia/osteoporosis and sarcopenia may increase the risk of early death. ${ }^{15}$

\section{The risk of obesity in postmenopausal women}

With the increase of age and the arrival of menopause, many postmenopausal women often develop obesity at the same time as the appearance of menopause syndrome. The cause of obesity after menopause is due to aging, decreased activity, reduced energy consumption in the body, and excess energy accumulated under the skin, and postmenopausal women have more total fat than premenopausal women. ${ }^{16}$ Postmenopausal women are 4.88 times more likely to develop abdominal obesity compared to premenopausal women. ${ }^{17}$ In addition, estrogen increases fat oxidation in skeletal muscles and inhibits fat formation in liver. ${ }^{18}$ Therefore, it can be expected that a lack of estrogen associated with menopause will lead to an increase in visceral fat mass, and increased fat in obesity will reduce bone density and increase the risk of osteoporosis. However, there is a contrary conclusion that ${ }^{19}$ fat mass is not an im- portant predictor of bone mineral density (BMD), and whether obesity threatens BMD is still to be strengthened.

Overweight and obesity also increase the risk of death, especially waist circumference and body mass index are related to the mortality of postmenopausal women with heart disease. ${ }^{20}$ Excess visceral fat is also an independent risk factor for cardiovascular mortality. Therefore, the maintenance of normal weight and avoidance of obesity in postmenopausal women are important measures to prevent chronic diseases. The adverse phenomenon of weight gain in postmenopausal women is not inevitable. These diseases can be effectively addressed by implementing the principles of a healthy lifestyle and using soy foods where appropriate and possible.

\section{CHANGES IN BODY COMPOSITION DUE TO HORMONAL CHANGES}

Hormonal fluctuations in postmenopausal women can lead to an increase in adipose tissue content, causing a change in the ratio of body fat percentage to lean body mass, leading to water loss and obesity. ${ }^{21}$ Compared with premenopausal women, postmenopausal women have higher obesity rate ${ }^{22}$ and experience symptoms of central obesity. ${ }^{23}$ At the same time, the decrease of estrogen leads to the loss of $\mathrm{BMD}$, which may directly affect the muscle tissue and thus increase the risk of osteosarcopenia. ${ }^{24,25}$ One of the most responsive pathways in musculoskeletal health is the mammalian target of rapamycin (mTOR), which is involved in several anabolic processes of skeletal muscle. ${ }^{26}$ The stimulus upstream of mTOR is insulin-like growth factor 1 (IGF-1), which is considered to be essential for muscle growth and regeneration. ${ }^{27-29}$ The estrogen receptor works on muscle strength through the actions of estrogen and 
IGF-1. Estrogen and IGF-1 have been shown to decrease with menopause, thereby increasing the levels of proinflammatory cytokines, leading to sarcopenia, and increasing the risk of physical disability through its role in muscle protein breakdown. ${ }^{30-32}$ Therefore, a decrease in IGF-1 levels during menopause and a loss of the protective effects on estrogen circulating cytokines can accelerate the loss of muscle mass. ${ }^{33}$

Postmenopausal osteoporosis affects 30\% of women, and 50 -year-old women have a $40 \%-50 \%$ chance of suffering from osteoporotic fractures for the rest of their lives. ${ }^{34,35}$ When the total $\mathrm{BMD}$ of the human body decreases during menopause, the loss of endogenous estrogen appears to have a greater negative impact on cancellous bone compared to cortical bone. ${ }^{36,37}$ Hormone replacement therapy (HRT) can increase muscle and bone mass and prevent bone fracture in postmenopausal women; however, it is currently not recommended for primary therapy for osteoporosis due to its harmful side effects. ${ }^{38}$

\section{CAN SOY FOODS IMPROVE BODY COMPOSITION?}

\section{Soy foods in postmenopausal women}

The European Society for Clinical and Economic Aspects of Osteoporosis and Osteoarthritis recommends an optimal dietary protein intake of 1.0-1.2 g/ kg body weight/day with at least $20-25 \mathrm{~g}$ of high-quality protein at each main meal, with adequate vitamin $\mathrm{D}$ intake at $800 \mathrm{IU} /$ day to maintain serum 25-hydroxyvitamin D levels $>50 \mathrm{nmol} / \mathrm{L}$ as well as calcium intake of $1,000 \mathrm{mg} /$ day. Alongside regular physical activity/exercise 3-5 times per week, this regimen can prevent the age-related deterioration of musculoskeletal health in postmenopausal women. Protein consumption is an important strategy to improve BC (loss of fat and muscle gain). Based on data from the United States Department of Agriculture Nutrition Database, we compared the nutrients of soy milk and milk (Table 2) and found that soy milk has (1) lower energy and (2) richer protein and (3) contains a larger amount of unsaturated fatty acids, and (4) does not contain any cholesterol. Therefore, soy milk is more suitable for postmenopausal women who are prone to obesity, low muscle mass, and bone loss. Adding soy to milk can significantly increase muscle mass and strength. ${ }^{39}$

\section{The effect of soy foods on muscle and bone}

Isolated soy protein (ISP) is a well-known supplement that has been reported to improve health, athletic performance, $\mathrm{BC}$, and energy use. ISP also contains naturally occurring compounds including isoflavones and saponins, which have antioxidant, anti-inflammatory, immunomodulatory, anti-cancer, and cardioprotective properties. ${ }^{40,41}$ It also contains branched chain amino acids (BCAA), which may have a positive effect on body weight regulation and muscle protein synthesis. ${ }^{42}$ BCAAs are obtained from ISPs, accounting for approximately $35 \%$ of the amino acids necessary for skeletal muscle formation. ${ }^{43}$ BCAAs have been shown to be the main carrier of amino nitrogen between visceral and peripheral tissues (including skeletal muscle), but more importantly they appear to be the most direct cause of muscle protein stimulation. ${ }^{44}$ Therefore, consuming BCAAs as a nutritional supplement can improve athletic performance and prevent muscle mass loss due to aging and disease. ${ }^{45}$

Soy contains phytoestrogens, whose chemical structure is very similar to that of human estrogen. Compounds called lignans and isoflavones in soybeans can mimic the sex hormone estrogen produced by the human body. ${ }^{46}$ Studies have shown ${ }^{47}$ that phytoestrogens can help prevent bone loss in aging women. Recent studies have shown that there is a positive correlation between habitual soybean intake and bone health in premenopausal women. Soy isoflavones have a bone-preserving effect on bone mass after ovariectomies. ${ }^{48}$ A study of postmenopausal women in Japan reported a significant positive correlation between soy proteins or isoflavone intake and spinal BMD. ${ }^{49}$ The mechanism by which soybeans may play a protective role is unclear. There is some suggestive evidence

Table 2. Comparison of the nutritional composition of soy milk and milk

\begin{tabular}{|c|c|c|c|c|c|c|c|c|c|c|c|c|c|}
\hline Food name & $\begin{array}{l}\text { Energy } \\
\text { (kcal) }\end{array}$ & $\begin{array}{l}\text { Protein } \\
\text { (g) }\end{array}$ & $\begin{array}{c}\text { Total fat } \\
\text { (g) }\end{array}$ & $\begin{array}{c}\text { Carbohydrate } \\
\text { (g) }\end{array}$ & $\begin{array}{l}\text { Calcium } \\
\text { (mg) }\end{array}$ & $\begin{array}{c}\text { Phosphorus } \\
\text { (mg) }\end{array}$ & $\begin{array}{l}\text { Cholesterol } \\
\text { (mg) }\end{array}$ & $\begin{array}{l}\text { Unsaturated } \\
\text { fatty acid (g) }\end{array}$ & $\begin{array}{l}\text { Magnesium } \\
\text { (g) }\end{array}$ & $\begin{array}{l}\text { Iron } \\
\text { (g) }\end{array}$ & $\begin{array}{l}\text { Calcium } \\
\text { (g) }\end{array}$ & $\begin{array}{l}\text { Niacin } \\
\text { (g) }\end{array}$ & $\begin{array}{c}\text { Folic acid } \\
\text { (g) }\end{array}$ \\
\hline Soy milk & 54 & 3.27 & 1.75 & 6.88 & 25 & 0.64 & 0 & 1.362 & 25 & 0.64 & 25 & 0.513 & 18 \\
\hline Milk & 61 & 3.15 & 3.27 & 4.78 & 113 & 0.03 & 10 & 1.007 & 10 & 0.03 & 113 & 0.089 & 5 \\
\hline
\end{tabular}


that the high consumption of soybeans is related to the production capacity of equol, which is a metabolite of soy isoflavones and may have a beneficial effect on bone loss. ${ }^{50,51}$ These promising findings require further evaluation.

Women who drink soy milk one or more times per day are $56 \%$ less likely to develop osteoporosis than women who do not drink soy milk, which is comparable to that $62 \%$ of the risk reduction of osteoporosis by drinking milk one or more times a day. ${ }^{38} \mathrm{Com}$ pared with milk-based protein, soy protein was found to have a greater effect on increasing serum IGF-1, especially in women who do not receive HRT. 52 The effects of soy protein ingredients and estrogen receptors may improve discomfort in postmenopausal women. Daidzein has been found to down-regulate ubiquitin-specific protease 19 expression through estrogen receptor $\beta$ and increase skeletal muscle mass in young female mice. ${ }^{53}$ Since IGF-1 is osteogenic and can stimulate muscle protein synthesis, we recommend that postmenopausal women eat more soy protein rich in IGF-1 to promote muscle regeneration and bone health, and improve their quality of life.

\section{Effect of soy foods on obesity}

Soybeans have a significant impact on improving the metabolic health of postmenopausal women. ${ }^{54}$ Increasing soy protein intake can improve blood lipids and is inversely proportional to obesity.

Table 3. Summary of the soy protein research experiments

\begin{tabular}{|c|c|c|c|c|c|}
\hline Author (year) & Study & Intervention & $\begin{array}{l}\text { Treatment } \\
\text { duration }\end{array}$ & $\begin{array}{l}\text { Outcome measure- } \\
\text { ment }\end{array}$ & Effect on outcome \\
\hline \multirow[t]{2}{*}{$\begin{array}{l}\text { Horiuchi et al. } \\
(2000)^{55}\end{array}$} & \multirow[t]{2}{*}{85 PW/Japanese } & \multirow{2}{*}{$\begin{array}{l}\text { Subjects with normal lumbar spine bone mineral } \\
\text { density (L2-4 BMD) were investigated by } \\
\text { questionnaire, and the calculated daily energy, } \\
\text { protein, soy protein, and calcium intake were } \\
\text { obtained. }\end{array}$} & & L2-4 BMD & $\begin{array}{l}\text { Positive correlation with soy protein intake } \\
\qquad(\beta=0.225, P=0.04)\end{array}$ \\
\hline & & & & $\begin{array}{l}\text { Urinary } \\
\text { deoxypyridinoline }\end{array}$ & $\begin{array}{l}\text { Negative correlation with soy protein intake } \\
(\beta=-0.08, P=0.03)\end{array}$ \\
\hline $\begin{array}{l}\text { Zhang et al. } \\
(2005)^{56}\end{array}$ & $\begin{array}{l}\text { 24,403 PW (March 1, } \\
\text { 1997-May 23, } \\
\text { 2000)/Shanghai }\end{array}$ & Usual soy food intake & $\begin{array}{l}\text { Biennial } \\
\text { in-person }\end{array}$ & $\begin{array}{l}\text { Risk factors of } \\
\text { osteoporosis, the } \\
\text { relative risks of } \\
\text { fracture }\end{array}$ & $\begin{array}{l}\text { After adjustment for age, major risk factors of } \\
\text { osteoporosis, socioeconomic status, and } \\
\text { other dietary factors, the relative risks ( } 95 \% \\
\text { confidence intervals) of fracture were } 1.00 \text {, } \\
0.72(0.62-0.83), 0.69(0.59-0.80), 0.64 \\
(0.55-0.76) \text {, and } 0.63(0.53-0.76) \text { across } \\
\text { quintiles of soy protein intake ( } P<0.001 \text { for } \\
\text { trend). }\end{array}$ \\
\hline \multirow[t]{2}{*}{$\begin{array}{l}\text { Aubertin-Leheudre } \\
\text { et al. }(2007)^{57}\end{array}$} & \multirow[t]{2}{*}{$\begin{array}{l}18 \text { Sarcopenic-obese } \\
\text { women }\end{array}$} & \multirow[t]{2}{*}{$\begin{array}{l}\text { 70mg of isoflavones per day (44-mg diadzein, } \\
\text { 16-mg glycitein, and 10-mg genestein) }\end{array}$} & \multirow[t]{2}{*}{$6 \mathrm{mo}$} & FFM & $\begin{array}{l}\text { The isoflavone group increased significantly } \\
\text { appendicular }(P=0.034) \text {, leg }(P=0.016) \text { FFM. }\end{array}$ \\
\hline & & & & $\mathrm{MMl}$ & $\begin{array}{l}\text { The isoflavone group increased significantly } \\
\qquad \mathrm{MMI}(P=0.037) \text {. }\end{array}$ \\
\hline \multirow[t]{3}{*}{$\begin{array}{l}\text { Choquette et al. } \\
(2013)^{58}\end{array}$} & \multirow{3}{*}{$\begin{array}{l}70 \text { Overweight-to- } \\
\text { obese; body mass } \\
\text { index, } 32.2 \pm 4.8 \\
\mathrm{~kg} / \mathrm{m}^{2} ; \mathrm{PW}, 59 \pm 5 \\
\text { years }\end{array}$} & \multirow[t]{3}{*}{$\begin{array}{l}\text { (1) Placebo }(n=15),(2) \text { isoflavones }(n=15) \text {, } \\
\text { (3) exercise and placebo }(n=20),(4) \text { exercise } \\
\text { and isoflavones ( } n=20)\end{array}$} & \multirow[t]{3}{*}{$6 \mathrm{mo}$} & $\begin{array}{l}\text { Leg press, bench } \\
\text { press }\end{array}$ & $\begin{array}{l}\text { Exercise produced } 49 \% \text { and } 23 \% \text { increases, } \\
\text { respectively, in leg press and bench press } \\
1 \mathrm{RM}(P \leq 0.01) \text {. }\end{array}$ \\
\hline & & & & $\begin{array}{l}\text { Leg relative strength } \\
\text { and muscle quality } \\
\text { in the legs }\end{array}$ & $\begin{array}{l}\text { Leg relative strength and muscle quality } \\
\text { increased by more than } 50 \% \text { (both } P<0.01 \text { ). }\end{array}$ \\
\hline & & & & Muscle mass index & $\begin{array}{l}\text { Muscle mass index increased by } 7 \%(P<0.05) \\
\text { in both exercise groups only. }\end{array}$ \\
\hline $\begin{array}{l}\text { Keshavarz et al. } \\
(2012)^{59}\end{array}$ & $\begin{array}{l}24 \text { Overweight and } \\
\text { obese female } \\
\text { adults }\end{array}$ & A diet with soy milk or a diet with cow's milk & 4 wk & Waist circumference & $\begin{array}{l}\text { Waist circumference was reduced } \\
\text { significantly following the soy milk period. }\end{array}$ \\
\hline $\begin{array}{l}\text { Llaneza et al. } \\
\qquad(2011)^{60}\end{array}$ & 87 Healthy obese PW & $\begin{array}{l}\text { Daily oral intake of a soy isoflavones extract } \\
\text { (Fisiogen) containing } 200 \text { mg of Glycine max }\end{array}$ & $6 \mathrm{mo}$ & $\begin{array}{l}\text { Leptin } \\
\text { TNF- } \alpha\end{array}$ & $\begin{array}{l}\text { Mean serum leptin levels declined. } \\
\text { TNF- } \alpha \text { levels declined. }\end{array}$ \\
\hline \multirow[t]{2}{*}{$\begin{array}{l}\text { Van Nielen et al. } \\
(2014)^{61}\end{array}$} & \multirow[t]{2}{*}{$\begin{array}{l}15 \text { PW with } \\
\text { abdominal } \\
\text { obesity }\end{array}$} & \multirow[t]{2}{*}{$\begin{array}{l}\text { One diet, protein of mixed origin; the other diet, } \\
\text { soy meat analogues and soy nuts containing } \\
30 \mathrm{~g} / \text { day soy protein. }\end{array}$} & \multirow[t]{2}{*}{$2-4 w k$} & $\begin{array}{l}\text { Frequently sampled } \\
\text { intravenous glucose } \\
\text { tolerance test }\end{array}$ & $\begin{array}{l}\text { The soy-protein diet resulted in greater insulin } \\
\text { sensitivity. }\end{array}$ \\
\hline & & & & Total cholesterol & $\begin{array}{l}\text { Lower after the soy-protein diet compared to } \\
\text { the mixed-protein diet. }\end{array}$ \\
\hline
\end{tabular}

PW, postmenopausal women; BMD, bone mineral density; FFM, fat-free mass; MMI, muscle mass index; RM, repetition maximum; TNF- $\alpha$, tumor necrosis factor-alpha. 
Soy proteins are associated with clinically significant weight loss. Studies in some obese animal models have shown that eating soybeans in a low-calorie diet can promote greater weight and fat loss, ${ }^{62,63}$ and that dietary soy protein intake is associated with improved obesity, decreased blood sugar and insulin, and improved lipid distribution and insulin sensitivity, so this shows that soy foods are effective in improving obesity. ${ }^{7-9}$ Liu et al.$^{64}$ found that isoflavone soy protein supplementation for 6 months reduced body weight and body mass index in the postmenopausal Chinese women with mild hyperglycemia. However, there are also studies ${ }^{9}$ showing that although soy isoflavone has a significant improvement trend due to its low heterogeneity, only genistein plays an important role in improving glucose metabolism. This demonstrates that the type of isoflavone seems to have a different effect on metabolism, requiring further investigation.

\section{CONCLUSION}

Over the past few decades, the consumption of dairy products has decreased, and has been replaced by soy foods for dairy products and widely used as a substitute beverage among people who avoid dairy products. Today, soy foods may improve the BC of menopausal and premenopausal women. To make it easier for readers to understand the benefits of soy foods for postmenopausal women, we have summarized some research experiments (Table 3 ) and proved that it not only delays the physical disabilities of menopausal women with osteosarcopenia and obesity, but it can also improve their muscle mass and bone strength to prevent the development of osteosarcopenia. In summary, this review focuses on the soy proteins and isoflavones contained in soy foods, which have an improved effect on osteogenesis and muscle growth while having an effect on weight loss and glucose metabolism. Although some studies have questioned the mechanism of the protective effect of soybean ingredients on certain metabolic diseases, it remains unclear and requires more future research.

\section{CONFLICTS OF INTEREST}

The authors declare no conflict of interest.

\section{ACKNOWLEDGMENTS}

This research was supported by Kyungsung University in 2019, Busan, Korea.

\section{AUTHOR CONTRIBUTIONS}

Study concept and design: all authors; acquisition of the data: ST; analysis and interpretation of the data: ST; drafting of the manuscript: ST; critical revision of the manuscript: all authors; statistical analysis: ST; obtained funding: JN; administrative, technical, and material support: JN; and study supervision: all authors.

\section{REFERENCES}

1. Ley CJ, Lees B, Stevenson JC. Sex- and menopause-associated changes in body-fat distribution. Am J Clin Nutr 1992;55:950-4.

2. Kanis JA, McCloskey EV, Johansson H, Cooper C, Rizzoli R, Reginster JY, et al. European guidance for the diagnosis and management of osteoporosis in postmenopausal women. Osteoporos Int 2013;24:23-57.

3. Cruz-Jentoft AJ, Landi F, Schneider SM, Zúñiga C, Arai H, Boirie Y, et al. Prevalence of and interventions for sarcopenia in ageing adults: a systematic review: report of the International Sarcopenia Initiative (EWGSOP and IWGS). Age Ageing 2014;43:748-59.

4. Binkley N, Buehring B. Beyond FRAX: it's time to consider “sarco-osteopenia”. J Clin Densitom 2009;12:413-6.

5. Ho SC, Chan SG, Yi Q, Wong E, Leung PC. Soy intake and the maintenance of peak bone mass in Hong Kong Chinese women. J Bone Miner Res 2001;16:1363-9.

6. Messina M. Soy and health update: evaluation of the clinical and epidemiologic literature. Nutrients 2016;8:754.

7. Chen JR, Zhang J, Lazarenko OP, Cao JJ, Blackburn ML, Badger TM, et al. Soy protein isolates prevent loss of bone quantity associated with obesity in rats through regulation of insulin signaling in osteoblasts. FASEB J 2013;27:3514-23.

8. Torre-Villalvazo I, Tovar AR, Ramos-Barragán VE, CerbónCervantes MA, Torres N. Soy protein ameliorates metabolic abnormalities in liver and adipose tissue of rats fed a high fat 
diet. J Nutr 2008;138:462-8.

9. Lavigne C, Marette A, Jacques H. Cod and soy proteins compared with casein improve glucose tolerance and insulin sensitivity in rats. Am J Physiol Endocrinol Metab 2000;278:E491500.

10. Glisic M, Kastrati N, Musa J, Milic J, Asllanaj E, Portilla Fernandez E, et al. Phytoestrogen supplementation and body composition in postmenopausal women: a systematic review and meta-analysis of randomized controlled trials. Maturitas 2018; 115:74-83.

11. Yoo JI, Kim H, Ha YC, Kwon HB, Koo KH. Osteosarcopenia in patients with hip fracture is related with high mortality. J Korean Med Sci 2018;33:e27.

12. Hamad B, Basaran S, Coskun Benlidayi I. Osteosarcopenia among postmenopausal women and handgrip strength as a practical method for predicting the risk. Aging Clin Exp Res 2019 Nov 2 [epub]. https://doi.org/10.1007/s40520-01901399-w

13. Huo YR, Suriyaarachchi P, Gomez F, Curcio CL, Boersma D, Gunawardene $\mathrm{P}$, et al. Comprehensive nutritional status in sarco-osteoporotic older fallers. J Nutr Health Aging 2015;19: 474-80.

14. Di Monaco M, Vallero F, Di Monaco R, Tappero R. Prevalence of sarcopenia and its association with osteoporosis in 313 older women following a hip fracture. Arch Gerontol Geriatr 2011; 52:71-4.

15. Huo YR, Suriyaarachchi P, Gomez F, Curcio CL, Boersma D, Muir SW, et al. Phenotype of osteosarcopenia in older individuals with a history of falling. J Am Med Dir Assoc 2015;16: 290-5.

16. Wietlisbach V, Marques-Vidal P, Kuulasmaa K, Karvanen J, Paccaud F; WHO MONICA Project. The relation of body mass index and abdominal adiposity with dyslipidemia in 27 general populations of the WHO MONICA Project. Nutr Metab Cardiovasc Dis 2013;23:432-42.

17. Donato GB, Fuchs SC, Oppermann K, Bastos C, Spritzer PM. Association between menopause status and central adiposity measured at different cutoffs of waist circumference and waistto-hip ratio. Menopause 2006;13:280-5.

18. Foryst-Ludwig A, Kintscher U. Metabolic impact of estrogen signalling through ERalpha and ERbeta. J Steroid Biochem Mol Biol 2010;122:74-81.

19. Li S, Wagner R, Holm K, Lehotsky J, Zinaman MJ. Relationship between soft tissue body composition and bone mass in perimenopausal women. Maturitas 2004;47:99-105.

20. Kanaya AM, Vittinghoff E, Shlipak MG, Resnick HE, Visser M, Grady D, et al. Association of total and central obesity with mortality in postmenopausal women with coronary heart disease. Am J Epidemiol 2003;158:1161-70.

21.Skrzypczak M, Szwed A, Pawlińska-Chmara R, Skrzypulec V. Assessment of the BMI, WHR and $\mathrm{W} / \mathrm{Ht}$ in pre- and postmenopausal women. Anthropol Rev 2007;70:3-13.

22. Dmitruk A, Czeczelewski J, Czeczelewska E, Golach J, Parnicka U. Body composition and fatty tissue distribution in women with various menstrual status. Rocz Panstw Zakl Hig 2018; 69:95-101.

23. Poehlman ET, Toth MJ, Gardner AW. Changes in energy balance and body composition at menopause: a controlled longitudinal study. Ann Intern Med 1995;123:673-5.

24. Phillips SK, Rook KM, Siddle NC, Bruce SA, Woledge RC. Muscle weakness in women occurs at an earlier age than in men, but strength is preserved by hormone replacement therapy. Clin Sci (Lond) 1993;84:95-8.

25. Carville SF, Rutherford OM, Newham DJ. Power output, isometric strength and steadiness in the leg muscles of pre- and postmenopausal women; the effects of hormone replacement therapy. Eur J Appl Physiol 2006;96:292-8.

26. Yoon MS. mTOR as a key regulator in maintaining skeletal muscle mass. Front Physiol 2017;8:788.

27. Musarò A, McCullagh K, Paul A, Houghton L, Dobrowolny G, Molinaro M, et al. Localized Igf-1 transgene expression sustains hypertrophy and regeneration in senescent skeletal muscle. Nat Genet 2001;27:195-200.

28. Pelosi L, Giacinti C, Nardis C, Borsellino G, Rizzuto E, Nicoletti C, et al. Local expression of IGF-1 accelerates muscle regeneration by rapidly modulating inflammatory cytokines and chemokines. FASEB J 2007;21:1393-402.

29. Rabinovsky ED, Gelir E, Gelir S, Lui H, Kattash M, DeMayo FJ, et al. Targeted expression of IGF-1 transgene to skeletal muscle accelerates muscle and motor neuron regeneration. 
FASEB J 2003;17:53-5.

30. Visser M, Pahor M, Taaffe DR, Goodpaster BH, Simonsick EM, Newman AB, et al. Relationship of interleukin-6 and tumor necrosis factor-alpha with muscle mass and muscle strength in elderly men and women: the Health ABC Study. J Gerontol A Biol Sci Med Sci 2002;57:M326-32.

31. Pfeilschifter J, Scheidt-Nave C, Leidig-Bruckner G, Woitge HW, Blum WF, Wüster C, et al. Relationship between circulating insulin-like growth factor components and sex hormones in a population-based sample of 50- to 80-year-old men and women. J Clin Endocrinol Metab 1996;81:2534-40.

32. Tsujinaka T, Ebisui C, Fujita J, Kishibuchi M, Morimoto T, Ogawa A, et al. Muscle undergoes atrophy in association with increase of lysosomal cathepsin activity in interleukin-6 transgenic mouse. Biochem Biophys Res Commun 1995;207:168-74.

33. Viña J, Sastre J, Pallardó FV, Gambini J, Borrás C. Role of mitochondrial oxidative stress to explain the different longevity between genders: protective effect of estrogens. Free Radic Res 2006;40:1359-65.

34. Johnell O, Kanis J. Epidemiology of osteoporotic fractures. Osteoporos Int 2005; 16 Suppl 2:S3-7.

35. van Staa TP, Dennison EM, Leufkens HG, Cooper C. Epidemiology of fractures in England and Wales. Bone 2001;29: $517-22$.

36. Berning B, Kuijk CV, Kuiper JW, Bennink HJ, Kicovic PM, Fauser BC. Effects of two doses of tibolone on trabecular and cortical bone loss in early postmenopausal women: a two-year randomized, placebo-controlled study. Bone 1996;19:395-9.

37. Seeman E. Age- and menopause-related bone loss compromise cortical and trabecular microstructure. J Gerontol A Biol Sci Med Sci 2013;68:1218-25.

38. Marjoribanks J, Farquhar C, Roberts H, Lethaby A, Lee J. Longterm hormone therapy for perimenopausal and postmenopausal women. Cochrane Database Syst Rev 2017;1:CD004143.

39. Orsatti FL, Maestá N, de Oliveira EP, Nahas Neto J, Burini RC, Nunes PR, et al. Adding soy protein to milk enhances the effect of resistance training on muscle strength in postmenopausal women. J Diet Suppl 2018;15:140-52.

40. Trock BJ, Hilakivi-Clarke L, Clarke R. Meta-analysis of soy intake and breast cancer risk. J Natl Cancer Inst 2006;98:459-71.
41. Ogawa M, Kitano T, Kawata N, Sugihira T, Kitakaze T, Harada N, et al. Daidzein down-regulates ubiquitin-specific protease 19 expression through estrogen receptor $\beta$ and increases skeletal muscle mass in young female mice. J Nutr Biochem 2017;49:63-70.

42. Galleano M, Calabro V, Prince PD, Litterio MC, Piotrkowski B, Vazquez-Prieto MA, et al. Flavonoids and metabolic syndrome. Ann N Y Acad Sci 2012;1259:87-94.

43. Landete JM. Updated knowledge about polyphenols: functions, bioavailability, metabolism, and health. Crit Rev Food Sci Nutr 2012;52:936-48.

44.Lin CL, Lee MC, Hsu YJ, Huang WC, Huang CC, Huang SW. Isolated soy protein supplementation and exercise improve fatigue-related biomarker levels and bone strength in ovariectomized mice. Nutrients 2018;10:1792.

45. Shimomura Y, Yamamoto Y, Bajotto G, Sato J, Murakami T, Shimomura N, et al. Nutraceutical effects of branched-chain amino acids on skeletal muscle. J Nutr 2006;136:529S-532S.

46. Adlercreutz H. Phytoestrogens: epidemiology and a possible role in cancer protection. Environ Health Perspect 1995;103 Suppl 7(Suppl 7):103-12.

47. Wahren J, Felig P, Hagenfeldt L. Effect of protein ingestion on splanchnic and leg metabolism in normal man and in patients with diabetes mellitus. J Clin Invest 1976;57:987-99.

48. Churchward-Venne TA, Breen L, Di Donato DM, Hector AJ, Mitchell CJ, Moore DR, et al. Leucine supplementation of a low-protein mixed macronutrient beverage enhances myofibrillar protein synthesis in young men: a double-blind, randomized trial. Am J Clin Nutr 2014;99:276-86.

49.Al-Anazi AF, Qureshi VF, Javaid K, Qureshi S. Preventive effects of phytoestrogens against postmenopausal osteoporosis as compared to the available therapeutic choices: an overview. J Nat Sci Biol Med 2011;2:154-63.

50. Vatanparast H, Chilibeck PD. Does the effect of soy phytoestrogens on bone in postmenopausal women depend on the equol-producing phenotype? Nutr Rev 2007;65(6 Pt 1):294-9.

51. Magee PJ, Rowland IR. Phyto-oestrogens, their mechanism of action: current evidence for a role in breast and prostate cancer. Br J Nutr 2004;91:513-31.

52. Arjmandi BH, Khalil DA, Smith BJ, Lucas EA, Juma S, Payton 
$\mathrm{ME}$, et al. Soy protein has a greater effect on bone in postmenopausal women not on hormone replacement therapy, as evidenced by reducing bone resorption and urinary calcium excretion. J Clin Endocrinol Metab 2003;88:1048-54.

53. Kalu DN. The ovariectomized rat model of postmenopausal bone loss. Bone Miner 1991;15:175-91.

54. Messina M. Soy and health update: evaluation of the clinical and epidemiologic literature. Nutrients 2016;8:754.

55. Horiuchi T, Onouchi T, Takahashi M, Ito H, Orimo H. Effect of soy protein on bone metabolism in postmenopausal Japanese women. Osteoporos Int 2000;11:721-4.

56.Zhang X, Shu XO, Li H, Yang G, Li Q, Gao YT, et al. Prospective cohort study of soy food consumption and risk of bone fracture among postmenopausal women. Arch Intern Med 2005; 165:1890-5.

57. Aubertin-Leheudre M, Lord C, Khalil A, Dionne IJ. Six months of isoflavone supplement increases fat-free mass in obese-sarcopenic postmenopausal women: a randomized double-blind controlled trial. Eur J Clin Nutr 2007;61:1442-4.

58. Choquette S, Dion T, Brochu M, Dionne IJ. Soy isoflavones and exercise to improve physical capacity in postmenopausal women. Climacteric 2013;16:70-7.

59. Keshavarz SA, Nourieh Z, Attar MJ, Azadbakht L. Effect of soymilk consumption on waist circumference and cardiovascular risks among overweight and obese female adults. Int J Prev Med 2012;3:798-805.

60.Llaneza P, González C, Fernandez-Iñarrea J, Alonso A, Diaz F, Arnott I, et al. Soy isoflavones, diet and physical exercise modify serum cytokines in healthy obese postmenopausal women. Phytomedicine 2011;18:245-50.

61. van Nielen M, Feskens EJ, Rietman A, Siebelink E, Mensink M. Partly replacing meat protein with soy protein alters insulin resistance and blood lipids in postmenopausal women with abdominal obesity. J Nutr 2014;144:1423-9.

62. Aoyama T, Fukui K, Takamatsu K, Hashimoto Y, Yamamoto T. Soy protein isolate and its hydrolysate reduce body fat of dietary obese rats and genetically obese mice (yellow KK). Nutrition 2000;16:349-54.

63. Nagasawa A, Fukui K, Funahashi T, Maeda N, Shimomura I, Kihara S, et al. Effects of soy protein diet on the expression of adipose genes and plasma adiponectin. Horm Metab Res 2002; 34:635-9.

64. Liu ZM, Ho SC, Chen YM, Ho YP. A mild favorable effect of soy protein with isoflavones on body composition-a 6-month double-blind randomized placebo-controlled trial among Chinese postmenopausal women. Int J Obes (Lond) 2010;34:309. 